\title{
ASGHAR ALI ENGINEER DAN PEMIKIRANNYA MENGENAI TEOLOGI PERDAMAIAN
}

\author{
Idan Dandi \\ UIN Syarif Hidayatullah Jakarta (idan.ilmiah@gmail.com)
}

\begin{abstract}
Asghar Ali Engineer is a progressive Muslim from India. When he was young and young he spent to read and master the works of the great Muslim thinkers of the Syī'ah Ismä'iliyyahalMusta'aliyyah al-Tayyibah who gave him the religious foundation. Moving into adulthood he also did not elude and blind from the fruit of the works of great Western philosophers, such as Bertrand Russell and Karl Marx. The religious and secular education that Asghar Ali Engineer got was not wasted. He applied the sciences in his social life. From these conditions, Ali Engineer developed into an active thinker and daring aspiring both in writing and down the street. Not a few views are devoted in the field of humanitarian, social, political and economic. All of the fields that they do have a purpose that is directed the peace that is wrapped with theology. In this paper, will be discussed the figure of Asghar Ali Engineer and the theology of peace that he brought.
\end{abstract}

Keywords: Peace, Peace Theology, Asghar Ali Engineer

\begin{abstract}
Abstrak
Asghar Ali Engineer adalah seorang Muslim progresif yang berasal dari India. Semasa kecil dan muda dihabiskannya untuk membaca dan menguasai buah karya-karya besar pemikir muslim aliran Islam Sȳ̄‘ah Ismā'iliyyahal-Musta āliyyah al-Ṭayyibah yang memberikannya fondasi keagamaan. Beranjak masa dewasa dia juga tidak menghindar dan membuta dari buah karya-karya para filsuf besar Barat seperti Bertrand Russell dan Karl Marx. Pendidikan agama dan sekuler yang didapatkan Asghar Ali Engineer tidak disia-siakannya begitu saja. Ilmu-ilmu tersebut ia aplikasikan dalam kehidupan sosialnya. Berangkat dari kondisi tersebut, Ali Engineer berkembang menjadi seorang pemikir yang aktif dan berani beraspirasi baik dalam tulisan maupun turun ke jalan. Tidak sedikit pandangannya dicurahkan dalam bidang kemanusiaan, sosial, politik dan ekonomi. Semua bidang yang digelutinya itu mempunyai tujuan yang terarah yakni perdamaian yang dibalut dengan teologi. Dalam tulisan ini, akan dibahas tentang sosok Asghar Ali Engineer beserta teologi perdamaiaan yang dibawakannya.
\end{abstract}

Kata-kata Kunci: Damai, Teologi Perdamaian, Asghar Ali Engineer

\section{A. Pendahuluan}

Isu seputar SARA (suku, agama, ras dan antargolongan) memang tidak ada habisnya di media massa. Isu SARA tidak hanya ada di Indonesia tapi di belahan bumi yang lain juga terdapat hal serupa. Terutama terkait isu seputar agama yang terus menggelitik para penikmat media massa bahkan termakan olehnya. Masih terdengar berita-berita di media masa tentang pemboman yang dilakukan sejumlah orang yang menyatakan dirinya Muslim. Pernyataan tersebut juga sudah menjadi suatu pukulan yang memilukan terhadap kaum Muslim lainnya. Ditambah juga dengan pernyataan media massa yang mengangkat isu tersebut menjadi lebih provokatif.

Tidak hanya isu-isu media massa yang saling sikut dan menyudutkan satu sama lain. Persoalan ekonomi juga tidak bisa diabaikan oleh masyarakat pada umumnya. Masih banyak kasus 
kelaparan di suatu negara karena tidak dapat menyejahterakan rakyatnya. Ekonomi yang sudah menjadi sebuah keharusan bagi masyarakat karena tuntutan kebutuhan yang tidak bisa ditawar lagi. Mengingat ekonomi merupakan pokok yang penting dalam memenuhi kebutuhan masyarakat agar terciptanya kemakmuran. Begitu juga dengan politik yang seringkali terdapat penyimpangan para kaum penguasa dalam memimpin suatu negara. Penyimpangan itu seperti penyalahgunaan kekuasaan untuk menindas kaum yang lebih lemah dari penguasa. Padahal idealnya suatu negara adalah dimana para penguasa yang dapat melindungi masyarakat dari segala kegiatan yang ada di dalamnya.

Dari masalah-masalah yang kompleks tersebut terdapat salah seorang teolog Muslim kenamaan dari India, Asghar Ali Engineer. Beliau aktif menulis isu-isu yang muncul pada masanya, salah satunya mengkritisi berita pemboman gedung World Trade Centre Amerika, meletakkan dasar atau inti ajaran Islam sehingga dapat berpolitik dengan baik dan menjalankan stabilitas perekonomian dalam suatu negara.

Semua itu ditunjukkan untuk mengangkat kembali suatu cita-cita yang dimana masyarakat untuk mendapatkan keadilan dengan tujuan utamanya yakni kedamaian.Kedamaian masyarakat yang terdapat ketenteraman dan ketenangan dalam menjalankan segala kehidupan sosial, ekonomi dan politik yang berasaskan Islam.Sehingga inti ajaran Islam tentang kedamaian itu dibahasnya dalam Teologi Perdamaian Asghar Ali Engineer.

\section{B. Sekilas tentang Asghar Ali Engineer}

Asghar Ali Engineer lahir pada 10 Maret 1939 di Salumba, Rajasthan, India. Ia lahir di keluarga Muslim yang taat dan priyayi ortodoks di Bohra. Ayahnya adalah seorang sarjana terpelajar yang membantu mendirikan majlis ulama Bohra yang mengurusi urusan dakwah. ${ }^{1}$ Ayahnya juga seorang 'Amil (pegawai Masjid yang mengelola zakat). Masa kecilnya, ia mendapatkan pelajaran keagamaan di antaranya tafsīr (komentar atau penjelasan atas firman Tuhan), ta'wīl (makna ayat al-Qur'ān yang tersembunyi), figh (yurisprudensi) dan hadīts (sabda Nabī Saw.).

Di samping itu, Asghar menekuni pelajaran bahasa Arab dasar dari

1 Bohra adalah masyarakat Muslim yang menganut paham Syī'ah Ismā'īliyyah. Asghar Ali Engineer, Islam Masa Kini, Tim Forstudia, terj., Cet. I, (Yogyakarta: Pustaka Pelajar, 2000), h. v. 
ayahnya kemudian mengembangkannya sendiri. Ia juga telah melalap habis seluruh karya utama dari Fatīmī Da'wah. ${ }^{2}$ Selain belajar ilmu agama, Ia juga belajar ilmu sekular. Ia adalah seorang alumni teknik sipil dari Universitas Indore (M.P.). Selama masa itu, beliau membaca tulisan-tulisan beberapa orang masyhur seperti Bertrand Russell $^{3}$, Das Kapital Marx ${ }^{4}$, Aḥmad

${ }^{2}$ Dalam History of Islamic Philosophy, tidak menyebutkan Ibn Manșūr al-Yamān dalam jajaran beberapa pemikir Syī'ah Ismā'īliyyah yang terkenal di zamannya. Nama yang tertulis di antaranya Qādī Nu'mān (363 H/974 M), Mu'ayyad fĩ al-Dīn al-Shirāzī (470 H/1077 M), Hamīd al-Dīn Kirmānī (408 H/1017 M), dan Abū Hātim Ahmad ibn Hamdan al-Rāzī (322 H/933 M). Henry Corbin, History of Islamic Philosophy, Liadain Sherrard, terj., (London: the Institute of Ismaili Studies, 1977), h. 76-77.

3 Bertrand Russell adalah seorang yang memeroleh hadiah Nobel dalam bidang sastra. Dia dikenal dunia sebagai orang nonkonformistis tentang moral dan politik. Pada tahun 50-an, dia juga memimpin aksi -aksi melawan persenjataan nuklir dan menulis karya tentang itu. K. Bertens, Filsafat Barat Kontemporer Inggris-Jerman, Cet. IV,(Jakarta: Gramedia, 2002), h.26; Common Sense and Nuclear Warfare adalah karyanya yang mendeskripsikan seruannya tentang ancaman nuklir yang dilegitimasi sebagai alat kekuasaan (politik) dunia. Bertrand Russell, Akal Sehat dan Ancaman Nuklir, Ira Puspito Rini, terj., (Yogyakarta: Ikon Teralitera, 2002), h. 1-4.

${ }^{4}$ Das Kapital (Modal)adalah salah satu adikarya Karl Max. Dia banyak berkutat dalam ketimpangan sosial seperti penindasan dalam masyarakat berkelas. Walaupun lebih dikenal sebagai ahli ilmu ekonomi tapi apabila dilihat lebih dalam dia dapat disebut sebagai filsuf yang humanistis. F. Budi Hardiman, Filsafat Modern: Dari Machiavelli sampai Nietzsche, Cet. II,(Jakarta: Gramedia, 2007), h. 234; Dia ingin menunjukkan bahwa kapitalisme jelas melahirkan kondisi-kondisi yang mengarah kepada kehancurannya dan memberi jalan bagi sosialisme. Dalam Das Kapital, dia membahas panjang lebar masalah nilai yang terdiri dari nilai
Khan $^{5}$ dan Maulānā Azad.

Reconstruction of Religious Thought in

Islam karya Muḥammad Iqbāl dibacanya

untuk memahami peran akal dan wahyu. $^{6}$ Salah satu yang menjadi perhatian khususnya adalah Rasā'il Ikhwān al-Șafă ${ }^{, 7}$ karena diyakini dan

guna (use value) terhadap barang yang dihasilkan dan nilai tukar (exchange value) adalah apa yang dibayarkan kepadanya. Henry J. Schmandt, Filsafat Politik: Kajian Historis dari Zaman Yunani Kuno Sampai Zaman Modern, Ahmad Baidlowi dan Imam Bahehaqi, terj., Cet. III, (Yogyakarta: Pustaka Pelajar, 2009), h. 521-524.

5 Ahmad Khan adalah orang yang mencegah segala bentuk kekerasan. Pada masa itu, dia banyak menolong orang Inggris dari pembunuhan. Sehingga dia diberi gelar Sir (salah satu gelar kebangsawan Inggris), tetapi dia menolaknya. Sampai akhir hayatnya tujuannya adalah ingin memajukan pendidikan umat Islam di negaranya (India). Abdul Rozak dan Rosihon Anwar, Ilmu Kalām, Cet. VII, (Bandung: Pustaka Setia, 2012), h. 217-218.

${ }^{6}$ Asghar Ali Engineer memercayai bahwa akal dan wahyu tidak bertentangan. Akal untuk pembangunan intelektual manusia tapi memiliki keterbatasan dan tidak mampu untuk menjawab segala pertanyaan mendasar mengenai makna akhir dan tujuan hidup. Kehadiran wahyu dimaksudkan untuk melengkapi akal dalam membangun kehidupan batiniah. Asghar Ali Engineer, Islam Masa Kini, h. viii; The Reconstruction of Religious Thought in Islam, merupakan tulisan filsafat Iqbal yang paling monumental yang berisi: a. Pengalaman dan Pengetahuan Keagamaan; b. Pembuktian Secara Filosofis mengenai Pengalaman Keagamaan; c. Konsepsi tentang Tuhan dan Makna Sembahyang; d. Tentang Ego-Insani, Kemerdekaan, dan Keabadian; e. Jiwa Kebudayaan Islam; f. Prinsip Gerakan dalam Struktur Islam; dan g. Apakah Agama itu Mungkin?. Hawasi, Eksistensialisme Mohammad Iqbal, (Jakarta: Wedatama Widya Sastra, 2003), h. 8-9.

${ }^{7}$ Rasā'il Ikhwān al-Safā' merupakan karya tulis sebanyak 52 risalah yang diklasifikasikan menjadi empat bidang: a. 14 risalah tentang matematika; b. 17 risalah tentang fisika dan ilmu alam; c. 10 risalah tentang ilmu jiwa; d. 11 risalah tentang ilmu-ilmu ketuhanan. Sirajuddin 
disusun oleh Imam-Imam Syī'ah Ismā'iliyyah pada abad ke- $8 \mathrm{H}^{8}$

Dari pendidikan teknik sipil, kemudian dia mengabdi sebagai seorang insinyur di Korporasi Kota Praja Bombay. Setelah 20 tahun di bidang tersebut, Ia mengundurkan diri dan terjun ke dalam gerakan reformasi Bohra. Ia memulai debutnya dengan memainkan peran penting dalam gerakan reformasi pada tahun 1972, saat pemberontakan di Udiapur.

Asghar aktif menulis artikel di beberapa Koran India terkemuka seperti The Times of India, Indian Express, Statesman, Telegraph, The Hindu, dan sebagainya. Ia terpilih sebagai Sekretaris Umum DPP Masyarakat Dāwudī Bohra dalam konferensinya yang pertama di Udiapur pada tahun 1977.

Pada masa-masa dalam gerakan, Ia berjuang sekuat tenaga dan mencurahkan waktu serta pikirannya demi hal besar tersebut. Hal besar itu adalah gerakan reformasi dan menginternasionalkan

Zar, Filsafat Islam; Filosof dan Filsafatnya, Cet. V, (Jakarta: Rajawali Pers, 2012).

${ }^{8}$ Asghar Ali Engineer juga berkeyakinan bahwa Ikhwān al-Ṣafā' adalah para ulama yang berasal dari sekte Syī‘ah Ismā'īliyyah. Asghar Ali Engineer, Islam Masa Kini, h. vii-viii; bersesuaian dengan A History of Islamic Philosophy, yang menyebutnya dirinya the Brethren of Purity (Ikhwān al-Șafā') yang muncul di Basrah. Majid Fakhry, A History of Islamic Philosophy, (New York, Columbia University Press, 2004), h. 168. gerakannya, baik dalam tulisan-tulisan maupun ceramah-ceramahnya.

Asghar Ali Engineer juga menelurkan karya yang banyak diakui yaitu tentang kekerasan komunal dan komunalisme di India sejak pecahnya kerusuhan besar di Jabalpur, India, pada tahun 1961. Ia dianugerahi gelar kehormatan (D.Lit) atas pertimbangan Universitas Calcutta akan karya tersebut pada bulan Februari 1983.

Dengan kegigihannya dalam memikirkan dan bergelut dalam masalah-masalah sosial. Ia banyak diundang dalam seminar-seminar di universitas-universitas, pemerintahan dalam negeri (India) maupun luar negeri. Selain mengajar di dalam negeri, Ia juga telah mengajar di berbagai universitas luar negeri di antaranya: Amerika Serikat, Kanada, Eropa, Indonesia, ${ }^{9}$ Malaysia, Jerman, Prancis, Thailand, Pakistan, Sri Lanka, Yaman, Meksiko,

9 Salah satu kedatangan Asghar Ali Engineer tercatat pada tahun 1993.Beliau diundang untuk berbicara mengenai Hak-Hak Perempuan dalam Islam oleh salah satu organisasi perempuan yang telah menerjemahkan bukunya dalam bahasa Indonesia.Pada Juni 2001, beliau juga pernah diundang dalam konferensi di Ujung Pandang Sulawesi Selatan tentang al-Qur'ān dan perdamaian dunia. Diundang juga beberapa universitas dari Indonesia dan para undangan dari negara-negara lain. Selain itu, beliau juga berkawan baik dengan Abdurrahman Wahid. Asghar Ali Engineer, Islam Masa Kini, h. 176183. 
Lebanon, Mesir, Jepang, Uzbekistan,

Rusia, Australia, dan sebagainya.

Pemahaman inter-religius (lintas agama) Asghar Ali Engineer mengantarkannya kepada berbagai penghargaan.Ia berkeyakinan dengan menunjukkan rasa hormat yang sama kepada semua agama dan memertimbangkan keyakinan beragama sebagai bagian penting bagi kehidupan yang bermakna.

Ia tidak dapat menerima begitu saja dogma-dogma yang diwariskan oleh para pendahulunya di masa silam. Ia percaya dengan konteks yang senantiasa berubah. Maka Islam juga harus direinterpretasikan dan dipikirkan ulang dalam bingkai isu-isu kekiniannya. Dengan cara ini, ia tidak akan membebek secara buta tapi merefleksikan dan mendalami lebih tentang Islam.

Karya tentang harmoni komunal Asghar Ali Engineer mendapatkan perhatian dan apresiasi serius dari pemerintahan India. Bertepatan dengan hari Republik India, Ia mendapatkan penghargaan National Communal Harmony Award pada tahun $1997 .{ }^{10}$

10 Robby H. Abror, "Gugatan EpistemologisLiberatif Asghar Ali Engineer”, dalam Listiyono Santoso dan Abd. Qodir Shaleh, ed., Epistemologi Kiri, Cet. I, (Yogyakarta: Ar-Ruzz Media, 2015), h. 301-303.
Di balik penghargaan itu memang Asghar Ali Engineer bukanlah orang yang dapat dipandang sebelah mata.Asghar tidak hanya pintar dalam menelurkan karya-karyanya yang banyak diakui. Asghar di samping dapat dikatakan sebagai pemikir, Ia juga berirama sebagai seorang aktivis. Tanggung jawab yang diembannya juga tidak kecil yakni sebagai pemimpin salah satu kelompok Syī'ah Ismā'iliyyahalMusta‘āliyyah al-Ṭayyibah, ${ }^{11}$ Dāwud̄

11 Syī'ah mengalami perpecahan ketika memutuskan siapa Imam pengganti setelah Ja'far al-Șādiqibn Muhammad al-Bāqir. Sehingga Syī'ah terjadi perpecahan di antara Sȳ̄'ah Itsnā 'Asyariyyah (yang mengakui Mūsā ibn Ja'far sebagai Imam ke-7) dengan Syī'ah Ismā'īliyyah. Garis dari Syī'ah Ismā'îliyyah, yaitu 'Alī (Imam ke-1), Hasan ibn 'Alī (Imam ke-2), Hussayn ibn 'Alī (Imam ke-3), 'Alī Zain al-'Ābid al-Dīn ibn Hussayn (Imam ke-4), Muḥammad al-Bāqir ibn 'Alī Zain al- 'Ābid al-Dīn (Imam ke-5), Ja'far alȘādiq ibn Muhammad al-Bāqir (Imam ke-6), dan Ismā‘̄il abn Ja'far al-Ṣādiq (Imam ke-7). Abdul Rozak dan Rosihon Anwar, Ilmu Kalām, h. 96. Dalam Ilmu Kalāmmilik Abdul Rozak dan Rosihon Anwar hanya menjelaskan sampai Syī'ah Ismā'īliyyah. Setelah Ismā'îl ibn Ja'far yang meneruskan tampuk kepemimpinan adalah Muhammad ibn Ismā‘̄il (Imam ke-8). Disinyalir bahwa imam ke-8 dan setelahnya menyembunyikan diri dari perlakuan keras Bani Umayyah terhadap Bani Abbas yang dibela oleh ahl al-bayt. Sampai Abdullah al-Mahdi mendirikan kekhalifahan Fațimiyyah di Tunisia, lalu dia menghilang. Setelah Imam Mustanșir Bi Allāh, aliran Syī'ah ini juga terpisah menjadi dua yakni Nizariyyah dan Musta'āliyyah. Kemudian, pasca al-Amir bi Ahkam Allāh. Syī'ah terpecah lagi menjadi dua al-Ṭayyibah dan al-Hafiziziyyah. Lihat Tim Riset Majelis Tinggi Urusan Islam Mesir, Ensiklopedi Aliran dan Madzhab di Dunia Islam, Irhma, dkk., terj., Cet. I, (Jakarta: Pustaka al-Kautsar, 2015), h. 47-60. Syī'ah ini banyak tersebar di daerah Pakistan dan sekitarnya. Taufik Rahman, Tauhid - Ilmu 
Bohras (Guzare Dāwudī) yang berpusat di Bombay, India. ${ }^{12}$

\section{Butir Pemikiran Asghar Ali Engineer} Mengenai Teologi Perdamaian

Teologi yang merupakan sebuah ilmu tentang ketuhanan serta hubungan Tuhan dengan dunia nyata, ${ }^{13}$ telah memberikan ruang bagi penggunanya (teolog) untuk mengeksplorasi inti ajaran dari suatu agama. Dari penjelahan tersebut nantinya akan memberikan seseorang keyakinan-keyakinan yang berdasarkan pada landasan yang kuat

Kalām, Cet. I, (Bandung: Pustaka Setia, 2013), h. 189.

12 Syī'ah al-Ismā‘īiliyyah al-Musta’āliyyah alȚayyibah India yang berlokasi di Bohra dikenal dengan Dāwūdi Bohras. Lihat Farhad Daftary, "Isma'ili", dalam Richard C. Martin, ed., Encyclopedia of Islam and the Muslim World: vol. 2, (New York: Macmillan Reference USA, 2004), h. 269; Henry Corbin, History of Islamic Philosophy, h. 77. Pemimpin dalam Syī'ah ini adalah $D \bar{a} ' \bar{l}$ yang mempunyai sembilan puluh empat kualifikasi untuk menyandang jabatan tersebut yang diringkas dalam empat kelompok, yaitu kualifikasi: (1) pendidikan; (2) administratif; (3) moral dan teoretikal; serta (4) keluarga dan kepribadian. $D \bar{a} ' \bar{l}$ juga harus tampil sebagai pembela umat yang tertindas dan berjuang melawan kezaliman. Dalam Epistemologi Kiri, menyebutkan Asghar Ali Engineer juga mempunyai semua kualifikasi tersebut. Robby H. Abror, "Gugatan Epistemologis-Liberatif Asghar Ali Engineer", dalam Listiyono Santoso dan Abd. Qodir Shaleh, ed., h. 303.

13 Dagobert D. Runes, The Dictionary of Philosophy, (New York: Philosophical Library, t.t.), h. 317; Lihat juga dalam Nicholas Bunnin and Jiyuan Yu, The Blackwell Dictionary of Western Philosophy, (Malden: Blackwell Publishing, 2004), h. 683. dan tidak mudah diombang-ambing oleh zaman. $^{14}$

Sedangkan damai dalam Oxford Advanced Learner's Dictionary of Current English diartikan dengan kata "peace" yang bermakna keadaan terbebas dari perang atau masyarakat yang kacau; tenteram dan tenang. ${ }^{15}$ Damai dalam al-Qāmūs 'Arabiyy Indūnisiyy diartikan dengan kata "alsalm" dan "al-silm" yang berasal dari verba سلم, keduanya bermakna Islam, damai dan selamat. ${ }^{16}$ Sedangkan bentuk verba lain kata اسلم itulah diturunkan kata yang berarti "the act of resignation to God." Terdapat dua pengertian, yaitu, ia menundukkan dirinya atau ia masuk dalam kedamaian. ${ }^{17}$ Damai dalam Kamus Bahasa Indonesia berarti tak ada perang; aman; tidak ada kerusuhan;

\footnotetext{
${ }^{14}$ Harun Nasution, Teologi Islam: Aliran-Aliran Sejarah Analisa Perbandingan, (Jakarta: UIPress, 2012), h. ix.

${ }^{15}$ Peace is state of freedom from war; freedom from civil disorder; rest, quite, and calm. AS Hornby, Oxford Advanced Learner's Dictionary of Current English, (Walton Street: Oxford University, 1987), h. 617

${ }^{16}$ Mahmud Yunus, Kamus Arab - Indonesia, (Jakarta: Hidakarya Agung, 1990), h. 177.

${ }^{17}$ Taufiqurrohman S, "Konsep Perdamaian Dalam al-Qur'an," artikel diakses pada tanggal 30 Desember 2016 dari http://bdkpalembang.kemenag.go.id/konsepperdamaian-dalam-al-quran/
} 
tenteram; tenang; keadaan tidak bermusuhan. ${ }^{18}$

Seperti yang telah dijelaskan pada term-term di atas tentang teologi dan damai. Teologi sebagai ilmu yang bertugas sebagai peletak dasar atau inti ajaran suatu agama dan damai yang merupakan cita-cita luhur yang ingin dicapai dan didambakan setiap ciptaanNya. Maka, teologi damai adalah ilmu yang membahas dasar ajaran agama tentang apa dan bagaimana mendapatkan suatu kedamaian yang diidamkan oleh setiap ciptaan-Nya di dunia.

Sebagai seorang teolog yang banyak mengkaji masalah sosial kemasyarakatan, Ali Engineer banyak membuat konsep-konsep tentang kerukunan hidup masyarakat. Pemikiran itu kemudian ia jabarkan ke dalam beberapa butir-butir khusus yang kemudian dikenal sebagai butir-butir pemikiran teologi perdamaian, yang terdiri dari:

\section{Meluruskan Makna Islam}

Sebelum masuk pembahasan tentang poin-poin teologi damai dalam Islam Asghar Ali Engineer. Dalam tulisan iniakan dijelaskan terlebih dahulu mengenai Islam yang sebenarnya yang jauh dari unsur kekerasan. Dalam

18 Tim Penyusun Kamus Pusat Bahasa, Kamus Bahasa Indonesia, (Jakarta: Pusat Bahasa, 2008), h. 309. tinjauan Asghar Ali Engineer, Islam selalu dihubungkan dengan tingkah laku para pembuat keonaran di dunia saat ini. Mereka menyatakan bahwa perbuatan kekerasan yang dilancarkan para teroris yang terjadi seperti pemboman di WTC di New York, Pentagon dan Washington disebut jihad. Ini menyebabkan persepsi para penduduk dunia bahwa Islam adalah agama pembawa kekerasan. Jihad menjadi sebuah slogan yang dinaikan oleh para kaum frustasi dengan membuat kekerasan dimana-mana. Bahkan diperparah dengan anggapan bahwa semua kekerasan yang mereka lakukan sebagai perang suci yang disahkan oleh Islam. $^{19}$

Dalam hal ini tidak ada keterkaitan sama sekali antara kekerasan dan agama. Kekerasan sebagaimana terlihat dimanamana hanya sebagai fenomena sosial dan politik. Walaupun di dalam al-Qur'ān mengatakan seputar perang, tapi hanya sekedar mendeskripsikan situasi politik dan sosial yang berlaku pada waktu itu. Oleh karena itu, perang atau kekerasan

19 Asghar Ali Engineer, Liberalisasi Teologi Islam: Membangun Teologi Damai dalam Islam, Rizqon Khamami,terj., Cet. I, (Yogyakarta: Alenia, 2004), h.182; Asghar Ali menyebutkan bahwa tidak benar, streotipe al-Qur'ān di tangan kiri dan pedang di tangan kanan. Lihat dalam Asghar Ali Engineer, Islam dan Teologi Pembebasan, Agung Prihantoro,terj., Cet. V, (Yogyakarta: Pustaka Pelajar, 2009), h. 211. 
bukanlah solusi yang diingkan oleh alQur'ān. $^{20}$

Dapat pula, dilihat perbedaan antara perdamaian dan kekerasan. Di antara keduanya ada yang ideologi dan empirik. Perdamaian adalah ideologi dan kekerasan adalah empirik. Kekerasan di dalam al-Qur'ān merupakan suatu jalan dalam siatuasi yang tidak terelakan, tapi perdamaian merupakan sebuah tujuan (norma). Ini dikarenakan di dalam agama Islam atau agama mana pun tidak menjadikan kekerasan sebagai bagian dari suatu tujuan yang ideal. ${ }^{21}$

Dalam hal ini, Allāh SWT. walaupun menciptakan potensi umat manusia untuk berbuat kekerasan (perang), tapi selain itu Dia juga menanamkan hasrat kuat untuk kedamaian, sebagaimana termaktub dalam Q.S. Al-Tīn [95]: 4-5.

Menurut Asghar Ali Engineer, sebagaimana dalam ayat di atas, bentuk paling sempurna ( $f \grave{\imath}$ aḥsan taqwīm)

20 Asghar Ali Engineer, Liberalisasi Teologi Islam, h. 183; Banyak golongan yang menyetujui ideologi Islam.Islam yang menjungjung tinggi revolusi dan demokrasi untuk menyejajarkan diri tanpa memandang dari mana asalnya.Menjadi daya tarik berbagai kalangan atau suku semakin mencintai Islam. Walaupun pada realitanya tidak sama seperti masih adanya benci-membenci antara mawalis (non-Arab) dan bangsa Arab pada masa Bani Umayyah - tutur Asghar Ali. Lihat dalam Lihat juga dalam Asghar Ali Engineer, Islam dan Teologi Pembebasan, h. 2013.

21 Asghar Ali Engineer, Liberalisasi Teologi Islam, h. 183. merupakan sebuah tujuan dan kehendak Allāh agar manusia terus menuju kepada perdamaian. Bentuk paling sempurna adalah orang-orang yang selalu tanggap dan peka terhadap lingkungan sekitarnya. Membantu kaum yang lemah dan tertindas untuk keselarasannya. $F \bar{l}$ ahsan taqwìm (bentuk paling sempurna) merupakan tingkatan yang paling tinggi dalam jihad dan harus dimiliki dalam diri setiap manusia. Orang-orang tersebut selalu dengan gigih melawan dan menghindari segala godaan, ketamakan dan kekuasaan. ${ }^{22}$

Bentuk paling rendah dari yang terendah (asfala sāfilìn) merupakan orang-orang yang selalu tergoda dengan harta serta tamak akan segala hal. Orangorang dalam bentuk ini selalu tidak peka terhadap segala macam penderitaan dan keresahan orang-orang yang lemah. Padahal di luar sana banyak sekali orang-orang yang membutuhkan tangan pertolongan dari para penguasa yang alim tapi sayang di antara mereka masih ada yang zălim dengan suara-suara orang kecil.

2. Mengkritisi Isu tentang Jihad: Perdamaian dalam Jihad

Jihad banyak sekali mendapat sorotan pada arti kewajiban bagi seluruh

\footnotetext{
22 Asghar Ali Engineer, Liberalisasi Teologi Islam, h. 183-184.
} 
muslim untuk melawan orang kafir. Dari arti tersebut, sebenarnya terdapat arti yang tidak hanya tertuju pada maksud di atas saja. Adapun jihad juga sering disalahpahami dan digunakan dalam arti berperang dengan sengaja melawan orang-orang kafir. Sesungguhnya, jihad lebih jauh lagi tidak dalam arti yang sempit. Dalam al-Qur'ān sendiri merupakan konsep multidimensi yang menunjukkan seperti dimensi historis, sosial, etis, dan abadi. ${ }^{23}$

Secara historis, apabila melihat sejarah masyarakat Arab pra-Islam sangat jauh sekali dari konsep demokratis modern.Masyarakat Arab pada waktu itu hanya mempunyai sukusuku. Setiap suku juga memiliki pandangan demokratisnya sendiri. Apabila suku-suku tersebut disatukan dalam satu wadah. Maka dapat dilihat, mereka tidak memiliki kesamaan dalam pandangannya. Sehingga segala permasalahan yang ada jauh dari esensi kata perdamaian dan berujung pada sikap kekerasan. ${ }^{24}$

Perilaku di atas, sampai Islam datang masih digunakan untuk memutuskan segala perkara (yakni

\footnotetext{
${ }^{23}$ Asghar Ali Engineer, Liberalisasi Teologi Islam, h. 100-101.

24 Asghar Ali Engineer, Liberalisasi Teologi Islam, h. 100-101; Lihat juga dalam Asghar Ali Engineer, Islam dan Teologi Pembebasan,h. 203204.
}

dengan kekerasan). Bahkan tidak dapat dipungkiri penyelesaian dalam bentuk perang masih terdapat dalam tubuh Islam. $^{25}$

Masalah kekerasan ini, pada dasarnya seringkali bersumber pada kepentingan-kepentingan politik. Sehingga, sufi yang mengetahui bahwa konsep jihad ini pasti akan digunakan dalam suatu perbuatan yang tidak layak. Lalu, para sufi selalu menjaga diri mereka dari para penguasa dan menegaskan kembali tentang jihad dalam aspek-aspek sosial dan moral. Penegasan ini dibutuhkan untuk menyelematkan konsep jihad yang kaya moral dan etika. Bukan jihad yang disalahgunakan untuk kepentingan pribadi (ketamakan) para penguasa. ${ }^{26}$

Jihad melalui jalan pedang (perang) sebenarnya dianjurkan bukan untuk tujuan agresif (melampaui batas), hal itu tertulis jelas dalam firman Allāh SWT. di dalam al-Qur'ān, Q.S. AlBaqarah [2]: 190).

Dari ayat di atas, Asghar Ali Engineer terlihat jelas menunjukkan dua hal yang penting. Pertama, berperang

\footnotetext{
${ }^{25}$ Walaupun Islam telah datang di tengah-tengah tradisi jahiliyyah.Tidak dapat dinafikan; suka atau tidak suka bahwa pola-pola tertentu masih berbau tradisi jahiliyyah. Lihat Asghar Ali Engineer, Islam dan Teologi Pembebasan, h. 204.

26 Asghar Ali Engineer, Liberalisasi Teologi Islam, h. 102-104.
} 
diperbolehkan bagi Muslimin ketika mereka diperangi terlebih dahulu. Kedua, ketika Muslimin berperang, sangat dilarang untuk berbuat melampaui batas (agresif). ${ }^{27}$

Pedang hanya merupakan dari sekian alat dan bukan juga satu-satunya senjata dalam jihad. Senjata yang sebenarnya adalah keyakinan diri dan usaha tanpa henti dengan menebarkan cinta dan kepekaan dalam menjalani kehidupan. Dalam hal ini, menegakkan kebaikan dengan pedang tidak bisa diaplikasikan dalam kehidupan. AlQur'ān mengatakan maw'izah alhasanah (menyampaikan sesuatu dengan jalan yang baik), dan hikmah (kearifan) merupakan jalan yang lebih mapan daripada dengan kekerasan. ${ }^{28}$

Jihad, di kalangan akademisi Arab mengartikannya sebagai berusaha keras. Asghar Ali Engineer mengutip dalam Mufradāt al-Qur'ān karya al-Rāghib. Pertama-tama mendiskusikan arti dari akar kata juhd, yang berarti bekerja keras atau berusaha keras. Sedangkan juhūd

27 Asghar Ali Engineer, Liberalisasi Teologi Islam, h. 105; Asghar Ali juga sangat menyayangkan perang yang banyak terjadi di abad pertengahan yang dilakukan dengan cara agresi dan penaklukan. Ini yang sangat tidak dianjurkan dalam Islam, begitu juga dengan Asghar sendiri.Lihat dalam Asghar Ali Engineer, Islam dan Teologi Pembebasan, h. 207-209.

28 Asghar Ali Engineer, Liberalisasi Teologi Islam, h. 106. berarti kapasitas tertinggi seseorang. Apabila dipadukan keduanya akan bermakna berusaha sampai kapasitas tertinggi seseorang. ${ }^{29}$

Al-Rāghib melanjutkan, 'al-jihād wa al-mujāhadah' berarti memberikan kemampuan tertinggi dalam memertahankan diri di hadapan musuh. Lalu, al-Rāghib membagi jihad menjadi tiga kelompok: (1) berperang melawan musuh; (2) melawan setan; dan (3) melawan dirinya sendiri, yaitu ketamakan dan mementingkan diri sendiri. $^{30}$

Firman Allāh SWT. juga memertegasnya dalam ayat berikut:

"Orang-orang yang beriman dan berhijrah serta berjihad di jalan Allāh dengan harta, benda dan diri mereka, adalah lebih tinggi derajatnya di sisi Allāh; dan itulah orang-orang yang mendapat kemenangan."(Q.S. Al-Tawbah [9]: 20); "Berangkatlah kamu baik

29 Asghar Ali Engineer, Liberalisasi Teologi Islam, h. 102.

30 Sesuai dengan yang al-Rāghib sebutkan tentang al-jihād wa al-mujāhadah:

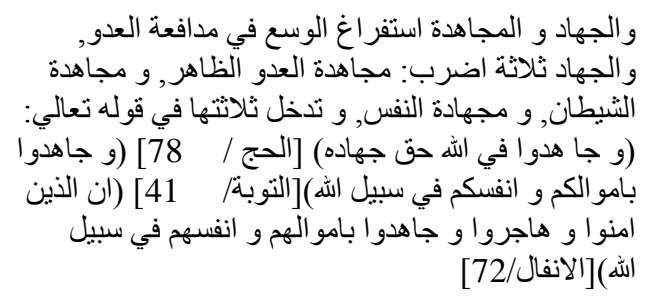

Ab̄̄ al-Qāsim al-Husayn ibn Muhammad alRāghib, al-Mufradāt Fi Gharīb al-Qurān, (Beirut: Dār al-Ma'rifah, 502 H), h. 101. Menurut Asghar Ali Engineer juga di kalangan pelajar bahasa Arab, jihad bermakna berusaha keras. Asghar Ali Engineer, Liberalisasi Teologi Islam, h. 102-103. 
dalam keadaan merasa ringan maupun berat, dan berjihadlah kamu dengan harta dan dirimu di jalan Allāhyang demikian itu adalah lebih baik bagimu, jika kamu mengetahui." (Q.S. AlTawbah [9]: 41).

Dua ayat di atas, menurut Asghar Ali Engineer, kata jihad di dalamnya mengandung pengertian berjuang dengan kekayaan dan dirinya sendiri (nyawa), bukan dalam pengertian perang atau balas dendam. Muslim saat di Mekkah terus berpegang teguh pada keyakinannya (Islam) dengan memertaruhkan nyawanya sendiri. Walaupun disiksa dengan segala cara tapi tidak menggoyahkan keimanan mereka. Di kalangan Muslim yang memiliki kekayaan melimpah juga memberikan hartanya demi membela Islam.Inilah yang disebutkan dalam alQur'ān sebagai jihad yang sebenarnya. ${ }^{31}$

Asghar Ali Engineer juga menunjukkan hadīts yang dikutip AlRāghib, "Perangilah hawa nafsumu

31 Asghar Ali Engineer, Liberalisasi Teologi Islam, h. 103; Asghar Ali mendeskripsikan ketika Nabi menawarkan perjanjian yang sangat menghargai orang-orang Yahudi di Madinah. Ternyata perlakuan itu tidak dibalas dengan kebaikan kembali.Sehingga terjadilah perang di Madinah antara kaum Yahudi yang dibantu saudagar-saudagar Mekah dan Muslim.Di Mekah juga Nabi dan para pengikutnya diperlakukan tidak selayaknya.Bahkan mereka akhirnya keluar dari Mekah dengan keadaan meninggalkan rumah dan harta benda; miskin. Asghar Ali Engineer, Islam dan Teologi Pembebasan, h. 207. sebagaimana kamu memerangi musuhmu. "Hadīts ini berkenaan dari maksud "jihad akbar". Mu'min diberi tanggung jawab oleh al-Qur'ān untuk menebarkan kebaikan dan memerangi kejahatan (amr bi al-ma 'rüf wa al-nahyi 'an al-munkar). Sehingga Muslim tidak henti-hentinya menahan hawa nafsu, menebarkan keadilan, persamaan dan kasih sayang dengan kearifan. Bukan dengan cara penindasan, ketidak-adilan, diskriminasi, dan kekejaman. Disebabkan perbuatan buruk tersebut akan menimbulkan meluasnya kejahatan yang lain dan misi para Mu'min untuk mencegahnya. $^{32}$

Banyak sekali cara jihad yang dianjurkan untuk membela dan mengangkat nama Islam. Berjuang dengan jalur moral dan intelektual: kearifan, penebaran kata-kata baik, menjadi tauladan atau contoh yang baik. Rasulullah SAW. berkata bahwa tinta seorang penulis adalah lebih suci daripada darah syahid.Dengan kata lain, kata yang ditulis penulis dengan tinta lebih abadi ketimbang darah syahid. ${ }^{33}$

Seorang Mu'min sebaiknya menghindarkan segala kemungkinan untuk condong kepada perang.

\footnotetext{
32 Asghar Ali Engineer, Liberalisasi Teologi Islam, h. 104-105

33 Asghar Ali Engineer, Liberalisasi Teologi Islam, h. 105.
} 
Memunculkan penyelesaian dengan jalan yang disepakati adalah jauh lebih penting. Rasulullah SAW. menyelesaikan segala permasalahan dengan jalan yang disepakati dari kedua belah pihak. Sedangkan perang diposisikan sebagai pembelaan diri jika segala usaha yang telah diupayakan telah gagal. ${ }^{34}$

Kerjasama (kesepakatan) bisa dilakukan tidak hanya dengan sesama Muslim, tapi dapat pula dengan nonMuslim. Kerjasama juga harus didasarkan pada sikap saling menghormati. Perdamaian Hudaibiyyah merupakan contoh kerjasama (kesepakatan) yang baik dalam sejarah Islam. Padahal dalam situasi tersebut Rasulullah SAW. tidak dalam situasi yang menguntungkan dengan segala syaratnya. Para sahabat juga merasa terhina dengan segala syarat tersebut. Namun Rasulullah SAW. menerima hal tersebut karena demi menghindarkan pertumpahan darah dan demi perdamaian yang menjadi sasaran utama. Perang hanya alternatif terburuk yang terpaksa diambil dalam situasi tidak terhindarkan. ${ }^{35}$

\footnotetext{
${ }^{34}$ Asghar Ali Engineer, Liberalisasi Teologi Islam, h. 106; Lihat juga dalam Asghar Ali Engineer, Islam dan Teologi Pembebasan, $\mathrm{h}$. 207-208.

35 Asghar Ali Engineer, Liberalisasi Teologi Islam, h. 107; Perjanjian Hudaibiyyah terjadi
}

Jihad selain dipandang sebagai perang, dapat pula dipandang sebagai pencipta keadilan sosial.Para Mu'min yang melakukan keadilan sosial tersebut dapat dikatakan sebagai Mujāhidīn (para pejuang di jalan Allāh). Abū Hurairah dalam Șahīh Bukhārī, Rasulullah Saw. bersabda:

"Seseorang yang memelihara dan bekerja untuk janda dan orang-orang miskin, seperti pejuang Allāh atau seperti seseorang yang berpuasa di siang hari dan salat sepanjang malam."36

Menanggapi hadìts di atas, menurut Asghar Ali Engineer, konflik yang sering diberitakan di berbagai belahan dunia tidak hanya menyangkut masalah kekuasaan. Kemiskinan, kelaparan dan pengangguran juga merupakan konflik yang belum

pada tahun 628 M dan Nabī Muḥammad Saw. datang sebagai pemimpin delegasi umat Islam. Perjanjian tersebut yang mendapat sorotan sentral bahwa orang-orang Mekah dan orangorang Islam harus mendapat perlakuan yang sama. Sehingga perang di antara keduanya secara praktis berakhir.Philip K. Hitti, History of The Arabs: From the Earliest Times to the Present, R. Cecep Lukman Yasin dan Dedi Slamet Riyadi, terj., (Jakarta: Serambi, 2010), h. 148.

${ }^{36}$ Dalamhadīts Bukhārī:

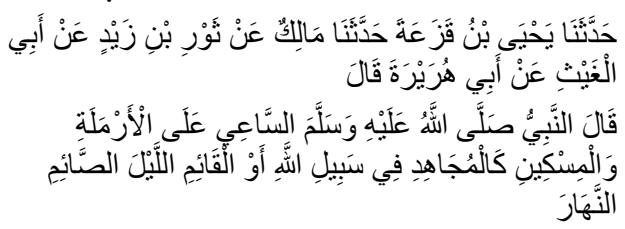

Lihat Bukhārī, “ Nafkah”, dalam Kitab 9 Imam 1.2, (Lidwa Pusaka i-software), no. Hadīts: 4934. 
terselesaikan. Bahkan mengakibatkan kepada permusuhan yang saling sikut satu sama lain. Oleh karena itu, harus dikumandangkan perang melawan kemiskinan dengan cara menumbuhkan produksi, pemerataan sumber-sumber ekonomi dan mencegah kekayaan yang berputar di kalangan para orang kaya saja. $^{37}$

Keadilan sosial diangkat dalam makna jihad karena banyak sekali ketidak-adilan dimana-mana.Sehingga perang pun tidak dapat terhindarkan dalam situasi tersebut. Demi membela hak-hak kaum lemah dari penguasa yang tamak. Dalam situasi masyarakat yang sudah modern dan demokratis, dapat memerangi para penguasa dengan gerakan demokrasi atau debat parlemen. Kemungkinan situasi dalam masyarakat modern tidak terdapat dalam al-Qur'ān ketika ayat tersebut diturunkan.Maka, hendak mereinterpretasikannya dengan kreatif terhadap hal-hal yang terjadi di masa sekarang. Dalam dunia modern, jihad sebenarnya adalah menggunakan demokrasi dan institusi untuk mewujudkan tujuan mulia seperti akhlak yang dipraktikan Rasulullah Saw. ${ }^{38}$

\footnotetext{
${ }^{37}$ Asghar Ali Engineer, Liberalisasi Teologi Islam, h. 107-108; Lihat juga dalam Asghar Ali Engineer, Islam dan Teologi Pembebasan, h. 206-207.

38 Asghar Ali Engineer, Liberalisasi Teologi Islam, h. 108-109.
}

3. Makmur dan Sejahtera:

Perdamaian dalam Ekonomi

Al-Qur'ān yang berperan sebagai penjawab segala macam pertanyaan sosial telah meletakan peran ekonomi berbasis kebutuhan dan menentang ekonomi berbasis ketamakan. Kekerasan awalnya berasal dari ketamakan manusia yang tidak pernah puas dengan apa yang dimilikinya. Dapat dibaca firman Allāh SWT. yang berbunyi dalam al-Qur'ān:

"Dan mereka bertanya kepadamu apa yang mereka nafkahkan. Katakanlah, yang lebih dari keperluan. Demikianlah Allāh menerangkan ayatayat-Nya kepadamu supaya kamu berfikir." (Q.S. Al-Baqarah [2]: 219).

Ayat tersebut, menurut Asghar Ali Engineer menunjukkan bahwa yang menafkahi pada diri sendiri hanya sesuai dengan kebutuhan pribadi (secukupnya). Sedangkan selebihnya dari harta itu disedekahkan kepada orang lain yang lebih membutuhkan. Masih dalam peran ekonomi terdapat konteks lain bahwa kekayaan tidak seharusnya berputar di antara orang kaya saja. ${ }^{39}$

Allāh SWT. menegaskannya kembali dalam ayat al-Qur'ān yang berbunyi:

\footnotetext{
39 Asghar Ali Engineer, Liberalisasi Teologi Islam, h. 184.
} 
"Berimanlah kamu kepada Allāh

dan Rasūl-Nya dan nafkahkanlah sebagian dari hartamu yang Allāh telah menjadikan kamu menguasainya. Maka orang-orang yang beriman di antara kamu dan menafkahkan (sebagian) dari hartanya memperoleh pahala yang besar.” (Q.S. Al-Hadīd [57]: 7); "Dan orang-orang yang menyimpan emas dan perak dan tidak menafkahkannya pada jalan Allāh, maka beritahukanlah kepada mereka, (bahwa mereka akan mendapat) siksa yang pedih." (Q.S. AlTawbah [9]: 34).

Dua ayat di atas, dideskripsikan Asghar Ali Engineer bahwa Allāh SWT. berkehandak untuk menciptakan perdamaian. Upaya-upaya yang dilakukan adalah dengan menuntaskan dari akar sosio-ekonomi dan konfliknya. Apabila sebuah negara tidak memberikan kebutuhan dasar masyarakatnya. Sedangkan negara mempunyai pembedaharaan kekayaan yang melimpah ruah dan para penguasa di dalamnya hidup makmur. Perdamaian tidak akan terwujud dalam negara yang tidak menegakkan keadilan seperti itu. Apabila hak kebutuhan dasar masyarakatnya saja tidak dapat terpenuhi. Maka tidak akan menutup kemungkinan terjadinya kekerasan dan konflik bertumbuh kembang di dalamnya. $^{40}$

Terdapat ayat yang menunjukkan sisi ideologi dan empirik yang bila dipandang dapat menunjukkan secara terpisah bahkan maksud keduakeduanya. ${ }^{41}$ Firman Allāh SWT.:

"Mengapa kamu tidak mau berperang di jalan Allāh dan (membela) orang-orang yang lemah baik laki-laki, wanita-wanita maupun anak-anak yang semuanya berdoa: 'Ya Tuhan Kami, keluarkanlah Kami dari negeri ini (Mekah) yang zālim penduduknya dan berilah Kami pelindung dari sisi Engkau, dan berilah Kami penolong dari sisi Engkau!'." (4: 75).

Terdapat tatanan ketidak-adilan seperti orang yang lemah menunjukkan mereka teraniaya dan akan melakukan pengambilan hak yang diambil dari mereka. Ini merupakan sisi empirik dari ayat tersebut. Sedangkan sisi ideologi dari ayat tersebut yakni meminta

\footnotetext{
${ }^{40}$ Asghar Ali Engineer, Liberalisasi Teologi Islam, h. 184; Pada masa kekhalifahan Umar terdapat perdebatan tentang harta rampasan perang.Tidak dapat dinafikan bahwa banyak orang yang berbondong berjihad.Tidak didasari dari ketulusannya membela Islam tapi hanya menginginkan harta.Banyak orang yang kaya mendapat tanah atau harta yang diberikan dari perang.Kemudian, Umar pun membuat kebijkan bahwa harta tersebut semuanya adalah milik negara dan digunakan untuk diambil manfaatnya bersama. Lihat juga dalam Asghar Ali Engineer, Islam dan Teologi Pembebasan, h. 211.

41 Asghar Ali Engineer, Liberalisasi Teologi Islam, h. 185.
} 
pertolongan dari Allāh untuk melepaskan ketidak-adilan. Disebabkan manusia pada hakekatnya tidak hidup dalam tatanan yang tidak adil. ${ }^{42}$

4. Pemimpin yang Adil: Perdamaian dalam Politik

Menurut Asghar Ali Engineer, terdapat penyalahgunaan kekuasaan (politik) untuk menindas yang lemah. Al-Qur'ān sendiri memberikan perhatiannya yang lebih intens tentang konflik antara mustakbirūn (orang-orang yang sombong) melawan mustậ'ifūn (orang-orang yang teraniaya atau lemah). ${ }^{43}$

Terdapat empat tokoh yang dapat diambil untuk contoh dalam konflik tersebut di antaranya Nabī Ibrāhīm A.S., Nabī Mūsā A.S., Namrūd dan Fir'aun. Peran protagonis disandarkan pada Nabī Ibrahim A.S. dan Nab̄̄ Mūsā A.S. Adapun peran antagonis diperankan pada Namrūd dan Fir'aun.

Peran protagonis disebut pembebas, yang membebaskan

42 Asghar Ali Engineer, Liberalisasi Teologi Islam, h. 185.

${ }^{43}$ Nabī Muhammad Saw. selalu berada dengan kaum tertindas yang memerlukan pertolongan tangannya. Dalam hal inial-Qur'ān memiliki dua perhatian yakni pada "manusia" secara umum dan kaum tertindas secara khusus. Pada praksisnya bentuk tertinggi kebenaran adalah membantu mereka yang dieksploitasi dan dianiaya. Farid Esack, Membebaskan yang Tertindas: al-Qur'ān, Liberalisme, Pluralisme, Watung A. Budiman, terj., Cet. I, (Bandung: Mizan, 2000), h. 246-247. mustậ'ifūn dari mustakbirūn dengan jalan yang lembut dan perjuangan serta mengantarkan mereka ke situasi dan tatanan yang adil. ${ }^{44}$

Kata mustaḍ 'ifün dan mustakbirūn yang dapat ditemukan dalam al-Qur'ān tidak hanya menunjukkan kepada sikap non-Muslim tapi juga berlaku bagi Muslim. ${ }^{45}$ Oleh karena itu, apabila menemukan seorang penguasa Muslim yang didapati tidak adil. Sebaik mungkin harus berjuang atau menempuhnya dengan jalur damai. Kekerasan (perang) memang dapat terjadi, tapi itu sangat tidak diharapkan oleh Rasulullah Saw. sekalipun. Semua tergantung pada situasi yang sedang dihadapi. Membicarakan kekerasan (perang) dan damai tidak bisa dibicarakan hanya dengan hipotesa. Konteks sosio-politik memainkan peran yang sangat penting dalam menentukan

${ }^{44}$ Asghar Ali Engineer, Liberalisasi Teologi Islam, h. 185.

${ }^{45}$ Dalam Q.S. Al-'Arāf [7]: 75 menggambarkan bahwa kaum penindas dan tertindas terdapat perbedaan antagonis dalam hal keimanan dan taraf kehidupan; Q.S. Sabā' [34]: 31-33 digambarkan tentang kaum penindas dan tertindas tidak selalu bertentangan dalam hal keimanan. Terdapat juga gambaran bahwa kaum penindas dan tertindas tidak selalu dari kalangan orang-orang kafir.Artinya, penindas dan tertindas sama-sama orang kafir. Abad Badruzaman, Teologi Kaum Tertindas: Kajian Tematik Ayatayat Mustad'afin dengan Pendekatan Keindonesiaan, Cet. I, (Yogyakarta: Pustaka Pelajar, 2007), h. 15. 
apakah damai yang dipilih, atau sebaliknya. $^{46}$

Perjuangan untuk menegakkan keadilan dan menebarkan keadilan tidak melibatkan Islam sebagai agama dengan agama lainnya saja, tapi antara penindas dan tertindas. Damai dan keadilan memang merupakan salah satu nilai Islam. Oleh karena itu, sebagai seorang Muslim selayaknya menegakkan keadilan dan kedamaian di dunia. Apabila ada seorang atau sekelompok orang melakukan kekerasan atas nama agama merupakan suatu kesalahan. Dikarenakan itu merupakan hal yang empirik dan bersangkutan terhadap diri pelaku sebagai pribadi bukan agama. Agama lain tidak pernah sama sekali bahkan Islam mengakui kekerasan sebagai norma. ${ }^{47}$

Beberapa ayat yang mengizinkan perang selalu didahului dengan kalimat "jika mereka memerangi kamu" dan " $f i$ sabīl Allāh(di jalan Allāh)". Perang dizinkan ketika mereka memerangi terlebih dahulu. Sedangkan fì sabīl Allāhmerupakan jalan Allāh dalam membatasi Muslim agar tidak berlebihlebihan dan agresif. Perang tersebut dilakukan untuk kedamaian, bukan untuk

\footnotetext{
46 Asghar Ali Engineer, Liberalisasi Teologi Islam, h. 186.

47 Asghar Ali Engineer, Liberalisasi Teologi Islam, h. 186-187.
}

kekuasaan serta tidak melibatkan dendam pribadi dan kelompok. ${ }^{48}$

\section{Penutup}

Setidaknya terdapat tiga saran yang dapat disampaikan dalam tulisan teologi damai dalam Islam menurut Asghar Ali Engineer ini. Pertama, untuk masyarakat awam agar tidak mudah percaya atau ikut terprovokasi dalam suatu ajaran atau ajakan seseorang sebelum mengetahui manfaat dan sebab-musababnya; kedua, untuk para cendikiawan setidaknya dapat memberikan pelajaran yang lebih baik untuk peserta didiknya dalam memberikan pengarahan tentang kedamaian dalam jihad; dan ketiga, untuk pemerintah terdapat banyak hal yang harus diperhatikan terutama dalam bidang politik dan ekonomi.

Dalam bidang politik, pemerintah juga wajib memiliki tanggung jawab dan jiwa yang besar dalam menduduki kepemimpinan serta sering turun atau terjun ke masyarakat untuk mendengarkan setiap aspirasinya. Sedangkan dalam bidang ekonomi, pemerintah wajib memberikan kesejahteraan yang merata serta memiliki rasa peka terhadap penderitaan orang lain di sekitarnya agar

\footnotetext{
48 Asghar Ali Engineer, Liberalisasi Teologi Islam, h. 187.
} 
termanifestasikan dengan masyarakat yang makmur di dalamnya.

\section{Daftar Pustaka}

\section{Buku:}

Ali Engineer, Asghar. 2004. Liberalisasi Teologi Islam "Membangun Teologi Damai dalam Islam, Rizqon Khamami, terj., Cet. I. Yogyakarta: Alenia. 2000. Islam dan

Teologi Pembebasan, Agung Prihantoro, terj. Cet. V. Yogjakarta: Pustaka Pelajar.

2000. Islam

Masa Kini. Tim Forstudia, terj.,Cet. I. Yogjakarta: Pustaka Pelajar.

Badruzaman, Abad. 2007. Teologi Kaum Tertindas: Kajian Tematik Ayat-ayat Mustad'afin dengan Pendekatan Keindonesiaan, Cet. I.Yogyakarta: Pustaka Pelajar.

Bertens, K. 2002. Filsafat Barat Kontemporer Inggris-Jerman, Cet. IV. Jakarta: Gramedia.

Bunnin, Nicholas and Yu, Ji yuan. 2004. The Blackwell Dictionary of Western Philosophy. Malden: Blackwell Publishing.

Corbin, Henry. 1977. History of Islamic Philosophy, Liadain Sherrard, terj. London: the Institute of Ismaili Studies.

Esack, Farid. 2000. Membebaskan yang Tertindas: Al-Qur'ân, Liberalisme, Pluralisme, Watung A. Budiman, terj.,Cet. I. Bandung: Mizan.

Fakhry, Majid. 2004. A History of Islamic Philosophy. New York, Columbia University Press.
Hardiman, F. Budi. 2007. Filsafat Modern: Dari Machiavelli sampai Nietzsche, Cet. II. Jakarta: Gramedia.

Hawasi. 2003. Eksistensialisme Mohammad Iqbal. Jakarta: Wedatama Widya Sastra.

Hitti, Philip K. 2010. History of The Arabs: From the Earliest Times to the Present, R. Cecep Lukman Yasin dan Dedi Slamet Riyadi, terj. Jakarta: Serambi.

Hornby, AS. 1987. Oxford Advanced Learner's Dictionary of Current English.Walton Street: Oxford University.

Martin, Richard C., ed. 2004. Encyclopedia of Islam and the Muslim World: vol. 2. New York: Macmillan Reference USA.

Nasution, Harun. 2012. Teologi Islam. Jakarta: UI-Press.

Rahman, Taufik. 2013. Tauhid - Ilmu Kalām, Cet. I. Bandung: Pustaka Setia.

Rozak, Abdul dan Anwar, Rosihon. 2012. Ilmu Kalām, Cet. VII. Bandung: Pustak Setia.

Runes, Dagobert D. t.t. The Dictionary of Philosophy. New York: Philosophical Library.

Russell, Bertrand. 2002. Akal Sehat dan Ancaman Nuklir, Ira Puspito Rini, terj. Yogyakarta: Ikon Teralitera.

Santoso, Listiyono, dkk. 2015. Epistemologi Kiri, Cet. I. Yogyakarta: Ar-Ruzz Media.

Schmandt, Henry J. 2009. Filsafat Politik: Kajian Historis dari Zaman Yunani Kuno Sampai Zaman Modern, Ahmad Baidlowi dan Imam Bahehaqi, 
terj., Cet. III. Yogyakarta: Pustaka Pelajar.

Tim Penyusun. 2008. Kamus Bahasa Indonesia. Jakarta: Pusat Bahasa.

Tim Riset Majelis Tinggi Urusan Islam Mesir. 2015. Ensiklopedi Aliran dan Madzhab di Dunia Islam, Irhma, dkk., terj., Cet. I. Jakarta: Pustaka al-Kautsar.

Yunus, Mahmud. 1990. Kamus Arab Indonesia. Jakarta: Hidakarya Agung.

Zar, Sirajuddin. 2012. Filsafat Islam; Filosof dan Filsafatnya, Cet. V. Jakarta: Rajawali Pers.
Internet:

S, Taufiqurrohman. "Konsep Perdamaian Dalam Al-Qur'an." artikel diakses pada tanggal 30 Desember 2016 dari http://bdkpalembang.kemenag.g o.id/konsep-perdamaian-dalamal-quran/

\section{Aplikasi:}

Quran In Word (Aplikasi)

Kitab 9 Imam Pusaka Lidwa i-Software (Aplikasi) 